\title{
Evaluation of The Feasibility and Importance of Using Statistical Analysis Models To Predict Financial Failure In The External Audit Profession
}

\author{
1Fedaa Abd Almajid Sabbar Alaraji and ${ }^{2}$ Talib Ghadhban Yaseen Alalawi \\ 1,2Craiova University, Faculty of Economics and Administration, Craiova, Romania Almustansiriya University, Iraq.
}

Correspondence Author: Fedaa Abd Almajid Sabbar Alaraji, Craiova University, Faculty of Economics and Administration, Craiova, Romania E-mail: fdaasabbar@yahoo.com

Received date: 22 December 2017, Accepted date: 22 January 2018, Online date: 5 February 2018

Copyright: (C) 2018 Fedaa Abd Almajid Sabbar Alaraji. This is an open-access article distributed under the terms of the Creative Commons Attribution License, which permits unrestricted use, distribution, and reproduction in any medium, provided the original author and source are credited.

\begin{abstract}
The subject of evaluating the ability of companies to continue in its activity or financial failure in the future is one of the important topics dealt with by academic and professional studies by universities and professional accounting and auditing organizations, especially after the collapses and financial failures of many international companies and the issuance of the International Auditing Standard No. (570) on the continuity of companies. our current study aims to focus the importance of using the models of predicting financial failure by the external auditor and the management of companies to evaluating the ability of these companies to continue or financial failure in the future The study has reached several conclusions, The most important is assessing the ability continuation of companies or their financial failure in the future by the external auditor and the management of companies in accordance with the guidelines of the International Auditing Standard No. (570) is necessary to avoid financial risks to companies and lead to financial failure and stop and liquidate legally, after criticisms and doubts about the usefulness and importance of the external audit profession and the research reached several recommendations, the most important Work on issuing local legislation in Iraq and Iraqi local accounting standards that require the management of Iraqi companies and external auditors in these companies to carry out the professional procedures necessary to assess the ability of these companies to continue their work or not in the future.
\end{abstract}

Key words: Financial failures, continuity, predict, methods.

\section{INTRODUCTION}

The subject of Prediction in the continuity of companies or financial failure in the future, as well as the responsibility of the external auditor and the management of companies in assessing the ability of companies to continue their activity or financial failure in the future of important subjects because of the negative impact on interested parties (shareholders, investors, banks and external auditor and government agencies and the economy as a whole) and have been taken from academic studies, studies, seminars and professional workshops by professional accounting and auditing boards and organizations.

The importance of this subject has increased in recent years, after many international companies have been exposed to financial collapses, financial failures and damage to all parties interested in these companies without prior warning by the external auditor and the management of companies indicated in their financial reports in previous years Financial failure, and our current study seeks to highlight the importance of awareness of the external auditor and the management of the company the need to use the methods of predicting financial failure as one of the methods of early warning about the probability of failure of the company financially in the future and our current study was divided into four axes The first axis of the methodology of the study, while the second dealt with the concept of financial failure and its importance and models of prediction and the third topic dealt with the study applied, while the fourth axis dealt with the conclusions reached.

First, the methodology of the study:

The problem of the study:

The problem of the study is the lack of awareness of the importance of using financial forecasting methods and models by the responsible parties (the management of the company and the external auditor) to assess the ability of companies to continue their activity and work or financial failure in future periods, despite the importance of these methods in providing indicators that can be an alert Ahead of the possibility of financial failure in the future.

\section{The importance and objective of the study:}

The importance of the subject of financial failure for all interested parties (management of the company, shareholders, investors, banks, creditors, government agencies, external auditor) is especially important. The study aims at shedding light on the importance of using the forecasting models of financial failure to assess the ability of companies to continue or their financial failure in the coming periods.

Second: The concept of financial failure and its importance and predictive models:

1. The concept of financial failure and forecasting: 
Financial forecasting is an attempt to visualize the financial position of the company in the future based on past and current information in order to meet the financial obligations that the company will face (Murad, 2003). The concept of financial forecasting for companies is defined as a set of procedures and subjective and subjective methods designed primarily for forecasting With the possible future events and knowledge of the results that will be achieved so that the prediction can be a big role by helping to provide the necessary results on the basis of which the evaluation process and make the appropriate decision in such a way that reduces the possibility of achieving deviations between what Actual and expected (Omar, 2005), also known as financial failure, is that voluntary work ceases due to financial default and is liquidated in this case by choice or due to a lawsuit that ends in favor of creditors and in this case is compulsory (Mattar, 2001).

The failure of the companies has two concepts, one economic and the other financial, the first is to measure success or failure based on the amount of return on capital and the company is failing when it is unable to achieve a suitable return on capital invested and appropriate and the expected risks and the second indicates the inability of the company to pay its obligations due (Alhbit, 2001). The failure of companies is also defined as the inability of the company to meet the financial obligations it has fully committed and is therefore in the process of bankruptcy and liquidation (Ashaur and El-Farra, 2005).

\section{2 - Financial failure:}

studies indicate that there are two aspects: (Saeed, 2000)

- The economic appearance of the failure of the company to achieve an appropriate return on the funds invested in this case applies to the company in achieving a return on investment less than the return cost of funds invested in it.

- Financial appearance is the company's arrival to the financial difficulty or beyond to the legal liquidation status and the company is legally insolvent when the carrying value of its assets become less than the carrying amount of its obligations, but reach the liquidation or bankruptcy if you fail to pay Debts.

\section{3 - The causes of financial failure: for financial failure reasons, including internal and external:}

Internal reasons: The following: (Alshabib, 2010)

- Loss of key markets, rights of franchise or major supplier.

- Problems in the labor force and shortage in the processing of materials and supplies.

- Loss of staff with administrative competence in leadership positions and inability to find replacements.

- The lack of use of the quality system in the work of the company, which in turn leads to higher costs and low profits and weak ability to compete and continue in the market.

- Increasing the current liabilities over the Company's current assets.

Or the most important external causes of financial failure are the following (Bani khaled, 2000):

- Economic conditions surrounding the corporate environment and lack of funding sources for necessary expansions.

- The high cost of funding sources.

- Pessimistic outlook for investors and financial analysts in the stock market and others.

- Intense competition.

There are several studies on the causes of financial failure, each of which gives reasons focused on the loss of the company to its main markets and the failure of the departments to attract the appropriate skills for planning processes and the inefficiency of administrative information system and fraud and the inability of companies to obtain long-term funding and the need for working capital and the expansion of projects (Abbas, 2010)

\section{4 - Stages of financial failure:}

There are indicators and factors of the financial failure of the company prior knowledge of the taking of the remedial procedures before the bankruptcy and financial failure. Opinions and studies differed about the stages of financial failure, including the study (Gordan, 1971):

1- The incubation phase: During this stage, indicators emerge as an early warning of the financial failure, such as low demand for products, increasing competition, lack of credit facilities and increasing burdens without working capital.

2- Liquidity Deficiency Phase: The stage of this phase is that the company's assets are greater than its liabilities, the inability of companies to meet their cash needs and the difficulty of transferring assets to cash assets to cover outstanding debts.

3. Financial Insolvency Stage: At this stage, companies suffer from the inability to cover their debts and pay their due fees and inability to obtain the necessary funds.

4 - Total Insolvency Stage: There are indicators at this stage predict the probability of failure of companies in the coming periods, including the dependence of companies on the loans and the deterioration of assets and liquidity ratios as well as the continuing rise in the volume of debt and the decline in profitability for consecutive periods and the inability of the company to compete.

5 - Stage of declaring bankruptcy: the final stage during which the company can not pay its debts where at this stage to waive its assets and to take legal procedures to protect the rights of creditors and at this stage the legal form of the company is gone by declaring bankruptcy and liquidation.

From these stages it turns out that the financial failure does not happen suddenly, but goes through several stages and each stage indicators and warning companies can take remedial measures at each stage to avoid financial failure.

\section{5 - The importance of predicting financial failure:}

The importance of financial failure stems from the interest of many interested parties, as follows:

- Banks: Banks are interested in predicting the financial failure because of the impact on their existing and restricted loans (Saleh \& Mohmed, 2000)

-Investors: Investors are interested in predicting financial failure for many reasons, including rationalizing their decisions, making tradeoffs between alternatives available, and avoiding risky investments (Raihan, 2006).

- Management: The attention of the management of the subject of financial failure to know the indicators of failure and its causes and procedures to address it before it occurs.

- Government agencies: These parties are concerned with the issue of financial failure as a supervisory function (such as the financial control department of operating companies and tax authorities and others).

- External auditors: Their interest in this matter is reflected in their being responsible for evaluating the continuity of companies or not.

\section{6 - Models used to predict financial failure of companies:}

Due to the difficulty of interpreting the results of the financial analysis using financial ratios and conflicting results, the researchers and financial analysts resorted to quantitative models composed of several ratios that can be used to predict financial failure of companies in future periods and below a presentation of the most common models used:

\section{-Model Altman and Mccough:}

a model adopted in 1968 and developed in 1995 and was used in this model to select five ratios considered to be characteristic of performance. This model has been widely used to predict the bankruptcy of companies because of the ability to predict many companies through this The model used a linear relationship between a set of variables that are best in distinguishing between failed companies and not failed companies. The model in its mathematical form is as follows:

$$
\mathrm{Z}=1.2 \mathrm{X} 1+1.4 \mathrm{X} 2+3.3 \mathrm{X} 3+0.6 \mathrm{X} 4+1.0 \mathrm{X} 5
$$

$\mathrm{X} 1=$ Net working capital on total assets.

$\mathrm{X} 2=$ Retained earnings and reserves / total assets.

$\mathrm{X} 3=$ Profit before interest and tax / total assets. 
$\mathrm{X} 4$ = Market value of equity / total liabilities.

X5 = Sales / Total Assets.

- When the value $(\mathrm{Z})$ is less than 1.81 , the probability of failure is large.

- When the value of $Z$ is greater than 2.99 , it is highly unlikely to fail. 2011).

- When the value of $(\mathrm{Z})$ between (1.81 and 2.99), it is difficult to judge the possibility of success or failure of the company and is called gray area (Hamza,

\section{-Model (Sherrod):}

This model is used to assess credit risk when granting bank loans and is used to predict business continuity and is based on six financial ratios:

$\mathrm{X} 1=$ Net Working Capital $/$ Total Assets (Liquidity Index).

$\mathrm{X} 2=$ Current Assets / Total Assets (Liquidity Index).

$\mathrm{X} 3$ = Total equity / total assets (index raised).

$\mathrm{X} 4=$ Net profit before tax / total assets (profit index).

$\mathrm{X} 5=$ Total assets / Total fixed assets (index of leverage).

$\mathrm{X} 6=$ Total equity / total fixed assets (index of leverage).

This model is in its mathematical form:

$\mathrm{Z}=17 \mathrm{x} 1+9 \times 2+3.5 \times 3+20 \times 4+1.2 \times 5+0.10 \times 6$

The risk index has been divided as shown in the table below (Mustapha, 2008):

\begin{tabular}{|l|l|l|}
\hline Group & The degree of risk of financial failure & The z value of the interval \\
\hline First & The company is not liable to bankruptcy & Z is greater than or equal to 25 \\
\hline Second & Low probability of exposure to bankruptcy risk & Z is greater than or equal to 20 and less than 25 \\
\hline Third & The risk of bankruptcy is difficult to predict & Z is greater than or equal to 5 and less than 20 \\
\hline Fourth & The company is exposed to bankruptcy risk & Z is greater than or equal to (5) and smaller than 5 \\
\hline Fifth & The company is highly exposed to bankruptcy risk & Z less than (5) \\
\hline
\end{tabular}

\section{-Model BEAVER:}

It is also a common model found in 1966 and is characterized by high predictive ability. However, it suffers from the fact that it is not based on scientific basis but rather for its prevalence. It uses a simple statistical method by dealing with the variables separately and thus can not be relied on to predict the future status of companies.

$\mathrm{X} 1=$ EBITDA $/$ total assets.

$\mathrm{X} 2=$ Net working capital / total assets.

X3 $=$ Sales $/$ Total Assets.

$\mathrm{X} 4$ = Market value of shares $/$ book value of debt.

$\mathrm{X} 5=$ Cumulative retained earnings $/$ total assets.

$\mathrm{Z}=3.3 \mathrm{X} 1+1.2 \mathrm{X} 2+1.0 \mathrm{X} 3+0.6 \mathrm{X} 4+1.4 \mathrm{X} 5$

- When $\mathrm{Z}$ is greater than 2.99 , the model expects the company to fail.

- When $(Z)$ is less than 1.81 it is expected that the company will fail.

- When $\mathrm{Z}$ is between $2.99-1.88$, the model can not identify the company as a failed or non - failed gray area.

This model succeeded in predicting failure just two years before and failing to predict bankruptcy.

\section{-KIDA Model:}

This model was found in 1981 and proved predictive (90\%) before bankruptcy for one year. This model is mostly applied to the banking sector (Othman, 2012). This model can be illustrated in the following mathematical form:

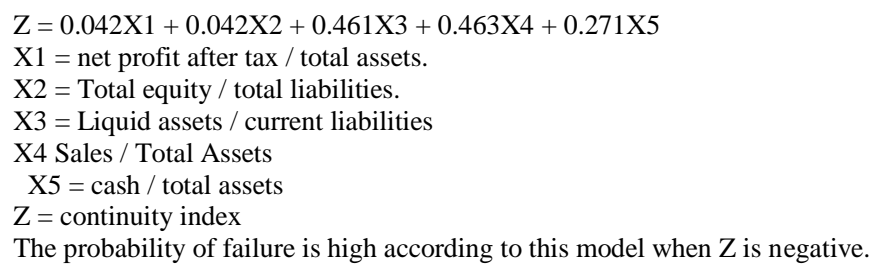

7 - The responsibility of the external auditor to assess the ability of companies to continuity or financial failure:

That the failure of companies or their ability to continue to have different indicators, including what the external auditor can reach during the normal examination, which is done to achieve the objectives of auditing recognized, including what requires special procedures and complex require the auditor a long and adequate experience and need special efforts and tests may require Additional costs Even for the auditor to do all the professional attention he may not reach this.

Therefore, the auditor shall be responsible if he fails to assess the ability of the company to continue with his ability to do so within the normal examination and then he is subject to professional, criminal and civil liability because the right may harm the company and society and contravene the instructions related to the profession.

The IFAC's Standing Standard No. 570 of the International Accounting Association (IFAC) sets forth guidelines on the external auditor's responsibility to ensure continuity as the basis for the preparation of financial statements.

\section{Third: Applied Study:}

Altman's model will be adopted in our applied study because of its high predictive ability in many companies by applying it to a sample of Iraqi companies listed in the Iraqi Stock Exchange for year 2013 and by applying the equation of the model:

$\mathrm{Z}=1.2 \mathrm{X} 1+1.4 \mathrm{X} 2+3.3 \mathrm{X} 3+0.6 \mathrm{X} 4+1.0 \mathrm{X} 5$

$\mathrm{X} 1=$ Net working capital on total assets.

$\mathrm{X} 2=$ Retained earnings and reserves / total assets.

$\mathrm{X} 3=$ EBITDA $/$ total assets .

$\mathrm{X} 4=$ Market value of equity / total liabilities.

X5 $=$ Sales / Total Assets. 
Citation: Fedaa Abd Almajid Sabbar Alaraji and Talib Ghadhban Yaseen Alalawi, 2018. Evaluation of The Feasibility and Importance of Using Statistical Analysis Models To Predict Financial Failure In The External Audit Profession. Australian Journal of Basic and Applied Sciences., 12(1): 10-14.

\begin{tabular}{|c|c|c|c|c|c|c|c|}
\hline & \multirow[b]{2}{*}{ Company } & \multicolumn{6}{|c|}{ Equation of the Altman model } \\
\hline & & $\mathrm{X} 1$ & $\mathrm{X} 2$ & $\mathrm{X} 3$ & $\mathrm{X} 4$ & $\mathrm{X} 5$ & ق قيمة \\
\hline 1 & Al-Kindi Veterinary Company & 0.565 & 0.0735 & 0.0252 & 20.16 & 0.54 & 13.33 \\
\hline 2 & Modern chemical industries Company & -0.031 & -0.64 & -0.29 & 2.47 & 0.46 & 0.02 \\
\hline 3 & National Food Company & 0.25 & -0.54 & 4.74 & -0.26 & 0.01 & 1.54 \\
\hline 4 & $\mathrm{Al}$ - Khazer Construction Company & -0.136 & -0.115 & -0.115 & 1.953 & 0.35 & 0.84 \\
\hline 5 & $\begin{array}{l}\text { Structural Materials Manufacturing } \\
\text { Company }\end{array}$ & 0.803 & -0.17 & 0.09 & 9.12 & 0.30 & 6.21 \\
\hline 6 & Modern sewing company & 0.769 & -0.27 & -017 & 9.38 & 0.34 & 5.932 \\
\hline 7 & $\begin{array}{l}\text { Ready Made Garments Manufacturing } \\
\text { Company }\end{array}$ & -0.168 & -0.955 & -0.283 & 1.62 & 0.38 & -1.09 \\
\hline 8 & Modern Dyes Company & 0.75 & 0.099 & 0.049 & 9.7 & 0.44 & 7.51 \\
\hline 9 & Light Industries Company & 0.285 & -0.178 & -0.084 & 0.74 & 0.29 & 0.57 \\
\hline 10 & $\begin{array}{l}\text { Iraqi Company for Engineering } \\
\text { Industry }\end{array}$ & 0.768 & 0.134 & 0.142 & 6.60 & 1.08 & 60625 \\
\hline 11 & Electronic Industries Company & 0.259 & -0.31 & -0.01 & 0.74 & 0.32 & 0.59 \\
\hline 12 & National Cycling Company & 0.338 & -0.1 & -0.1 & 0.78 & 0.19 & 0.58 \\
\hline
\end{tabular}

Source: prepared by author.

Table 2: Successful And Unsuccessful Companies According To The Results Of Application Of Altman Model

\begin{tabular}{|l|l|l|l|}
\hline \multicolumn{1}{|c|}{ No. } & Failed Companies $(\mathrm{Z}<1.81)$ & No. & \multicolumn{1}{|c|}{ Successful Companies (Z> 2.99) } \\
\hline 1 & Eastern Beer Company & 1 & Al-Kindi Veterinary Company \\
\hline 2 & National Food Company & 2 & Structural Materials Manufacturing Company \\
\hline 3 & Al - Khazer Construction Company & 3 & Modern sewing company \\
\hline 4 & Ready Made Garments Manufacturing Company & 4 & Modern Dyes Company \\
\hline 5 & Light Industries Company & 5 & Iraqi Engineering Industries Company \\
\hline 7 & Electronic Industries Company & & \\
\hline
\end{tabular}

Source: Source: prepared by author.

Analysis of the results:

By comparing the value of the index $(\mathrm{Z})$ with the elements of the equation which are important indicators that give early warning of the companies' exposure to future failure as follows:

The ratio of net working capital, which is one of the liquidity ratios, is strongly linked to the value of (Z). For the first indicator (X1), the ratio of net working capital is low and the ratio of net working capital is low Or lack of liquidity, which indicates that the company is achieving losses and has the ability to pay its obligations, which is one of the causes of financial failure and non-continuity of companies.

- For the second indicator (X2), which represents the percentage of retained earnings to total assets, it is noted that this ratio in most companies sample study with low rates and indicate the non-distribution of profits is also indicative of a cumulative deficit in those companies or lack of liquidity and can be observed Companies with low $\mathrm{Z}$ value suffer from a decrease in retained earnings.

- For the third indicator (X3), which represents the ratio of profit before interest and taxes to total assets, which is also called the rate of return on investment and this rate of indicators, which gives early warning of the continuation or failure of the company in the future There is a strong relationship between the value of $\mathrm{Z}$ and the return on investment The lower the $\mathrm{Z}$ value, the lower the rate of return on investment and vice versa.

- The fourth indicator (X4) represented by the market value of shareholders 'equity. This percentage is an important indicator that shows the ability of the company to pay its obligations through the assets of these companies. This ratio shows the relationship between the shareholders' equity and the debts incurred by the company. The better the company, and the lower the ratio indicates an increase in the debts of the company compared to its assets and thus the inability of the company to pay its obligations is one of the indicators of failure of companies in the future, noting that the decline in most of the companies that the value of $\mathrm{Z}$ is low.

- For the fifth indicator (X5) of the ratio of sales to assets and according to this ratio, the decrease will lead to a decrease in the value of $\mathrm{Z}$ and that the decline in this ratio is an indication of the inefficiency of the management of these companies in the exploitation of their assets in achieving high sales.

Fourth: Conclusions and Recommendations:

Conclusion:

The researcher reached the following conclusions:

-Companies practice their activities in an environment of various risks that increase the likelihood of companies failing and their financial failure and thus their inability to continue their activity and work. Therefore, the process of predicting financial failure is a very important issue that has been addressed by many researchers and financial analysts in addition to the importance of the financial failure of each auditor And the management of the company as parties interested in the continuity of companies or financial failure. Our current study has reached several conclusions summarized as below:

- The process of predicting financial failure is necessary to avoid the financial risks that may be exposed to companies and lead to financial failure and then stop them from practicing and liquidation of these companies.

- The management of companies is responsible for the preparation of the final financial statements of the companies and also the responsibility of evaluating the ability of the company to continue its activities and practice.

- The External Auditor is responsible for carrying out several procedures to assess the Company's ability to continue its activities within the scope of the necessary professional care as required by International Auditing Standard No. 570.

- There are several stages passed by the companies before the arrival of the stage of financial failure and each phase a set of indicators on the management of the company and the external auditor to be guided to determine the status of the company and take the necessary procedures to solve the problem.

- Financial forecasting models for companies in the coming period rely on the financial information published in the financial statements of the companies. These ratios contain a set of financial ratios. The Altman model is one of the most accurate models for predicting the failure of companies.

- The results of the analysis of the main financial indicators of some companies in the sample of the study showed that there is weakness in their performance through many negative indicators that emerged in the results of the analysis, which confirms the probability of failure in future periods and the management of these companies to take the corrective measures necessary for their performance to ensure the continuation of activity and non-exposure For fiscal failure in the coming quarters. 
- Work on issuing local legislation in Iraq and Iraqi local accounting standards that require the management of Iraqi companies and external auditors in these companies to carry out the professional procedures necessary to assess the ability of these companies to continue their work or not in the future.

- Working to increase academic and professional curricula in Iraqi universities and institutes in the fields of financial analysis, financial failure and forecasting models.

- Working to stimulate professional accounting organizations to establish professional workshops for the definition and to demonstrate the importance of using models predicting financial failure in Iraqi companies to increase the awareness of the managements of companies and external auditors to the need to use these models to predict their ability to continue its work or financial failure in the future.

\section{REFERENCES}

Abbas, Ali. G., 2010. Determine the administrative and financial reasons for the failure of companies, Middle East university,journal of Baghdad college of Economic scienes, 25: 12 .

AlShabib and Durai Kamel, 2010. Mangement financial companies ,House Albzuri publishing, Jorden, pp: 245.

Alhbit, Qasim, 2001. Useof financial analysis models to test the imposition continue accounting firms, Rafidain development Journal, 64: 221.

Bani Khaled, M., 2003. The role of credit analysis in the reduction of loan default, PhD thesis, University of Almosul, Iraq, p: 39.

IFAC, International standard on auditing (570)Going concern, 2010. Accessed on December, 2014.

Gordan, 1971. Towardsa theory of financial distress, the journal of financial.

Hamza, Al-Zubaidi, 2011. Financial analysis for the purposes of performance evaluation for predicting financial failure, Iraq, p: 307.

Mattar, Mohammed, 2001. The nature and importance of financial failure corporate indicators, Albsaer journal ,petra university, Jordan, p: 20.

Murad, Kasm. S., 2010. operating, cash flow forecasting, Master's thesis, Yarmouk university, Jordan, p: 23.

Mustapha Fahmy, Sheikh, 2008. Financial analysis, Phalestine.

Othman Mohamed Daoud, 2012. Mangment and analysis of credit, House Alfik publishing, Jorden, p: 88.

Omer, Mohamed \& Hazm, Alsrag, Estimate prediction models to predict stock prices in the Arab capital markets,Masters thesis Jordan, p: 44

Raihan, Sharif, 2006. Issue of the efficiency and effectiveness of quantitative models for predicting bankruptcy, Journal of Human Sciences, Jordan, p: 33.

Saleh, Essam. M. and Ghazwan, Munir, 2008. corporate survival analysis to predict the financial failure ,PhD Thesis, university of Almosul, p: 178.

Saeed Abd Salam, 2000. Bank credit Arab Italian, House publishing, Italia, p: 363.

Yousif, H.M. Ashour and Majed M. El-FARROC, 2002. business failure in the gaza strip bankers and business expets,viewpoint,journal of Islamic university of Gaza, 10: 1.

\section{Highlights:}

-This article is very important by highlighting the importance of using the methods of predicting financial failure in the process of evaluating the ability of Iraqi companies of various kinds to continue to work or to face future financial failure.

-This article aims to raise awareness among the users of the financial statements in all countries of the world of the importance of adhering to the professional accounting standards related to assessing the ability of companies to continue their activity.

-This article represents a simple addition in the field of scientific research related to international professional accounting standards, valuation tools and financial analysis. 